\title{
SMITHSONIAN INSTITUTION RADIOCARBON MEASUREMENTS I
}

\author{
JOEL J. SIGALOVE* and AUSTIN LONG \\ Division of Radiation and Organisms, Smithsonian Institution, \\ Washington 25, D. C.
}

\section{INTRODUCTION}

The radiocarbon dating laboratory at the Smithsonian Institution, Division of Radiation and Organisms, was established in September 1962. After careful calibration with known samples and refinements in the methane synthesis system, routine analysis of samples was begun in the spring of 1963.

Standard sample pretreatment consists of hand removal of foreign matter such as rootlets, and leaching in hot $2 \% \mathrm{NaOH}$ followed by hot $5 \% \mathrm{HCl}$. Shells are washed in $\mathrm{HCl}$ until their weight is reduced by $25 \%$.

Methane, the counting gas, is produced catalytically from $\mathrm{CO}_{2}$ by a method patterned after that of Fairhall's (Fairhall et al., 1961). Yields of greater than $95 \%$ are obtained consistently. The samples of methane are stored for two weeks after synthesis and counted at least twice for a period of more than $1000 \mathrm{~min}$ each.

The counter has a $2.2 \mathrm{l}$ active volume with a 0.5 mil center wire, and is constructed of OFHC copper, teflon and epoxy plastic. Surrounding the counter is 1 in. of mercury, then a methane-filled, multiple anode proportional guard counter (anti-coincidence counter). This unit is immersed in a steel tank filled with 5 tons of mercury, resulting in 6 in. of mercury shielding on the sides and 12 in. on top.

The counter is operated at a pressure of $63 \mathrm{in}$. $\mathrm{Hg}$ at 3900 volts. The background is $5.4 \mathrm{cpm}$ and the ages were calculated using 0.950 of the activity of the NBS oxalic acid $(24.3 \mathrm{cpm})$. The standard deviation indicated represents only the $1 \sigma$ of the counting statistics.

\section{Interlaboratory Check Samples}

\begin{tabular}{rccl}
\hline SI No. & SI Age & $\begin{array}{c}\text { Other C-14 } \\
\text { Age on Sample }\end{array}$ & \multicolumn{1}{c}{ Reference } \\
\hline 3 & $10,900 \pm 145$ & $11,365 \pm 290$ & $\begin{array}{l}\text { OWU-6 (Written communication, } \\
\text { J. G. Ogden, III, Dec. 18, 1962) }\end{array}$ \\
4 & $17,145 \pm 210$ & $20,100 \pm 1100$ & $\begin{array}{l}\text { OWU.8 (Written communication, } \\
\text { J. G. Ogden, III) }\end{array}$ \\
$\dagger 4$ & $16,555 \pm 250$ & & Arizona III \\
9 & $2,820 \pm 115$ & $2,700 \pm 150$ & Arizona IV \\
\hline 10 & $160 \pm 80$ & $250 \pm 55$ &
\end{tabular}

* Present address: Isotopes, Inc., Westwood, N. J.

$\dagger$ A duplicate analysis made on additional sample material. 


\section{SAMPLE DESCRIPTIONS}

I. GEOLOGIC SAMPLE

\section{SI-27. New Providence Island, Bahamas}

Peat from near sea level, above truncated coral reef and overlain by unconsolidated sand and silt, Lyford Cay Club yacht basin excavation $\left(25^{\circ} 01^{\prime}\right.$ $30^{\prime \prime}$ N Lat, $77^{\circ} 32^{\prime} 05^{\prime \prime}$ W Long), Bahamas. Coll. 1960 and subm. by D. F. Squires, Div. of Marine Invertebrates, Smithsonian Inst. Comment: the peat probably had been accumulating throughout much of post-Pleistocene time, as its thickness reaches $16 \mathrm{ft}$.

\section{ARCHAEOLOGIC SAMPLES}

\section{A. North America}

\section{Winslow site series, Maryland}

Charcoal from the Winslow site (18-MO-9) in Montgomery County $\left(39^{\circ}\right.$ 04' $05^{\prime \prime} \mathrm{N}$ Lat, $77^{\circ} 23^{\prime} 52^{\prime \prime}$ W Long). Coll. 1962 by R. G. Slattery and W. A. Tidwell; subm. by Clifford Evans, Div. of Archaeology, U. S. Natl. Mus., Smithsonian Inst.

\section{SI-37.}

$$
635 \pm 80
$$

Charcoal from Refuse Pit 12, 48 to 55 in. depth. Associated with sherds from Late Woodland Period. The earlier date of A.D. $837 \pm 150$ (M-1189, Michigan VIII, p. 243) from a nearby pit was not part of the same series of refuse pits as this sample. Comment (C.E.) : reanalysis of the pottery of the earlier pit is now required to justify the differences and see if another occupation is clearly distinguished by the pottery. Date agrees with the Late Woodland occupation of area.

\section{SI-41.}

$665 \pm 100$ A.D. 1285

Charcoal from House I-31, associated with Marcey Creek series sherds but directly underneath Late Woodland Period materials. Comment (C.E.) : date confirms that sample is from the Late Woodland Period.

\section{SI-44. Shepard site, Maryland $\quad \mathbf{4 3 0} \pm \mathbf{7 0}$}

Charcoal from Burial Pit 1, Square 26D, Shepard Barracks site $\left(39^{\circ} 05^{\prime}\right.$ $00^{\prime \prime} \mathrm{N}$ Lat, $77^{\circ} 27^{\prime} 17^{\prime \prime} \mathrm{W}$ Long), Montgomery County, Site 18-MO-4. Coll. 1962 by R. G. Slattery and W. A. Tidwell; subm. by Clifford Evans. The associated materials are of Late Woodland Period. Comment (C.E.) : this site has identical cultural materials to Hughes and Keyser Farm sites, both of which have been interpreted as Late Woodland; hence date corroborates the cultural designation.

\section{Medicine Creek series, Nebraska}

Site 25FT17 $\left(40^{\circ} 23^{\prime} \mathrm{N}\right.$ Lat, $100^{\circ} 14^{\prime} \mathrm{W}$ Long), on Medicine Creek, ca. $8.5 \mathrm{mi} \mathrm{N}$ of Cambridge, Frontier County, representing Upper Republican 
Culture. Coll. 1948 by M. F. Kivett and G. S. Metcalf; subm. by W. R. Wedel, Head Curator of Anthropol., Smithsonian Inst. Wood from a nearby house pit (Feat. 15) has been dated at A.D. $1170 \pm 125$ (I-585, Isotopes III, p. 73).

SI-32.

$830 \pm 65$

A.D. 1120

USNM T1371. Post butt in prehistoric square earthlodge, Feat. 30.

SI-34.

$1485 \pm 65$

A.D. 465

USNM T1660. Unburned wood fragments from square house fill, Feat. 70,16 to 24 in. depth. Comment (W.R.W.) : date seems much too early.

SI-36.

A.D. 1085

$865 \pm 65$

USNM T1630. Unburned wood fragments from square house, Feat. 66, 14 to 20 in. depth.

SI-40.

$710 \pm 65$

A.D. 1240

USNM T1766. Well-preserved post butt from square house, Feat. 90, 20 to 37 in. depth.

\section{Medicine Creek Reservoir series, Nebraska}

Juniper wood from post butts in sites in Frontier County $\left(40^{\circ} 8^{\prime} \mathrm{N}\right.$ Lat, $100^{\circ} 14^{\prime} \mathrm{W}$ Long), representing prehistoric farming villages of the Upper Republican Culture. Coll. 1948 by M. F. Kivett and G. S. Metcalf; subm. by W. R. Wedel. Comment: sample from another house ruin (Feat. 30) in Site 25FT70 was dated at A.D. $1450 \pm 200$ (M-844, Michigan V, p. 41).

SI-47.

A.D. 1160

$790 \pm 65$

USNM T2705. Juniper wood from butt of NW center post from rectangular house, Feat. 4.

SI-50.

$1070 \pm 70$

No. T2632. Entrance post, rectangular house, Site 25FT70.

SI-53.

$845 \pm 65$

A.D. 1105

No. T2702A. Center post from rectangular house F4, Site 25FT70.

\section{SI-56.}

No. T2523. From rectangular house, Site 25FT39.
$750 \pm 65$

\section{Lower Cheyenne River site series, South Dakota}

Stanley County $\left(44^{\circ} 46^{\prime} \mathrm{N}\right.$ Lat, $100^{\circ} 43^{\prime} \mathrm{W}$ Long), Site 39ST1. Samples are unburned juniper wood from post butts in long rectangular houses, probably Thomas Riggs Focus. Coll. and subm. by W. R. Wedel. 
SI-12.

$$
1030 \pm 60
$$

A.D. 920

USNM 422229. Feat. 102 in house, Feat. 34. Coll. 1955. Comment: sample from same post butt dated A.D. $1175 \pm 125$ (I-581, Isotopes III, p. 71).

SI-15.

\section{A.D. 1150}

$800 \pm 60$

USNM 421991A. In situ in house site, Feat. 24. Coll. 1951. This house is in same village with SI-12 and SI-17, and is considered culturally identical with them.

\section{SI-17.}

$870 \pm 60$

USNM 422230. Feat. 103 in house, Feat. 34. Coll. 1955. Comment: sample from this same post butt dated A.D. $1300 \pm 200$ (M-840, Michigan V, p. 40)

\section{SI-25. Molstad site, South Dakota}

$475 \pm 100$

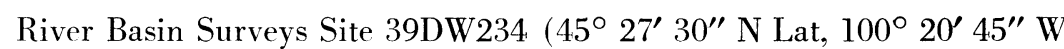
Long), Dewey County. Post butt from palisade bastion in W sector of fortified area, $1.25 \mathrm{ft}$ depth. Coll. 1962 by J. J. Hoffman; subm. by R. W. Neuman, Missouri Basin Project, 1517 O St., Lincoln, Nebraska. Comment: this date agrees with tree ring date of A.D. 1500.

\section{SI-48. Grover Hand site, South Dakota}

$1720 \pm 75$

River Basin Surveys Site 39DW240 (45 26 $36^{\prime} 30^{\prime \prime} \mathrm{N}$ Lat, $100^{\circ} 20^{\prime} 30^{\prime \prime} \mathrm{W}$ Long). Wood from Mound 3 in brown silt fill within central subfloor burial (N95, W80). Coll. 1962 and subm. by R. W. Neuman.

\section{Langdeau Village series, South Dakota}

Charcoal samples from Site 39LM209 (44. $08^{\prime} \mathrm{N}$ Lat, $99^{\circ} 36^{\prime} \mathrm{W}$ Long), representing a previously undescribed complex within the broad Middle Missouri Tradition. Coll. 1962 by R. E. Jensen; subm. by R. W. Neuman.

\section{SI-51.}

$$
950 \pm 65
$$

No. 332 from fill of Feat. 60, a bell-shaped cache pit in floor of Feat. 4, a long rectangular house.

\section{SI-54.}

$$
850 \pm 55
$$

\section{A.D. 1100}

No. 1523 from fill of Feat. 58, a large bell-shaped cache pit in Feat. 11, a long rectangular house.

\section{SI-57.}

$$
\mathbf{8 1 0} \pm \mathbf{7 0}
$$

\section{A.D. 1140}

No. 1036 from surface of floor, Feat. 10, a long rectangular house with wide bench extending across front. 


\section{B. South America}

\section{Valdivia Culture series, Ecuador}

Guayas Province $\left(1^{\circ} 56^{\prime} \mathrm{S}\right.$ Lat, $80^{\circ} 45^{\prime} \mathrm{W}$ Long). Earliest Formative Period pottery culture from Ecuador with ceramic forms and decoration showing relationships to Early-Middle Jomon Period materials from Kyushu, Japan. Shell midden refuse from stratigraphic excavations. Coll. 1961 by E. Estrada, B. J. Meggers and Clifford Evans; subm. by Evans, Div. of Archaeol., U. S. Natl. Mus., Smithsonian Inst. Series of dates from the Period A and Period B parts of the Valdivia Culture based on artifact and pottery changes in the sequence.

General comment: see dates from W-630, W-631, W-632 (USGS V, p. 181) and M-1317, M-1318, M-1320, M-1321, M-1322 (Michigan IX) for additional cross-dating in same sequence.

\section{SI-16.}

$4220 \pm 100$

2270 в.c.

No. 872-A. Anomalocardia subimbricata from 3.90 to $4.20 \mathrm{~m}$ depth in Stratigraphic Cut J, Sec. E. Period A, Valdivia Culture.

\section{SI-18.}

$4230 \pm 100$

2280 в.c.

No. 872-B. Anomalocardia subrugosa from 3.90 to $4.20 \mathrm{~m}$ depth in Stratigraphic Cut J, Sec. E. Period A, Valdivia Culture. Comment: both samples SI-16 and SI-18 are two different species of shell from same layer of midden refuse and give comparable dates to those obtained from charcoal (cf. SI-22).

\section{SI-20.}

$2805 \pm 105$

No. 870. Fine ash, dust type of charcoal from Stratigraphic Cut J, Sec. E, 3.30 to $3.60 \mathrm{~m}$ depth. Period A-B, Valdivia Culture. Submitted to see validity of this type of fine dust-ash sample in midden refuse as compared to shell and large fragments of charcoal. Comment: in view of other Valdivia Culture dates, this date suggests that sample was contaminated with more recent materials.

\section{SI-22.}

$$
\begin{aligned}
& 4450 \pm 90 \\
& 2500 \text { B.C. }
\end{aligned}
$$

No. 847. Charcoal from Stratigraphic Cut J, Sec. D, 3.00 to $3.30 \mathrm{~m}$ depth. Period A, Valdivia. Comment: dates in same range as SI-16 and SI-18, shell samples from same cultural period of refuse.

\section{Pepa de Huso series, Ecuador}

Manabi Province ( $1^{\circ} 3^{\prime}$ S Lat, $80^{\circ} 34^{\prime} \mathrm{W}$ Long), Site M-55, Pepa de Huso. Charcoal samples in stratigraphic cut representing the Late Chorrera Period as determined by pottery classification. Coll. 1961 by E. Estrada; subm. by Clifford Evans.

General Comment (C.E.) : samples SI-35 and SI-43 agree with time sequence on coast of Ecuador.

\section{SI-35.}

No. 1023.2 .60 to $2.80 \mathrm{~m}$ below surface. 


\section{SI-42.}

$1100 \pm 105$

No. 1024. 2.80 to $3.00 \mathrm{~m}$ below surface. Comment (C.E.) : because of the consistence of SI-35 and SI-43 and because of the expected age on the basis of cultural association, this material is considered intrusive into the section. Date is within estimated range (500 to 1000 A.D.) for the Chirije Culture, represented in the upper levels at the site.

\section{SI-43.}

$$
2540 \pm 125
$$

No. 1025.3 .00 to $3.20 \mathrm{~m}$ below surface.

\section{Esteros series, Ecuador}

Charcoal samples from Site M-7 (57' S Lat, $80^{\circ} 4 \mathrm{l}^{\prime}$ W Long), Manabi Province, Ecuador. Three samples from Stratigraphic Cut A, associated with pottery of the Bahia Culture. Coll. 1961 by E. Estrada, Clifford Evans, and B. J. Meggers; subm. by Evans. Comment (C.E.) : in agreement with estimated range of culture based on pottery sequences.

SI-49.

$2300 \pm 65$

No. 988.3 .20 to $3.40 \mathrm{~m}$. 350 в.C.

\section{SI-52.}

$2350 \pm 65$

No. 989.3 .40 to $3.60 \mathrm{~m}$.

400 в.c.

SI-55.

No. 991.3 .80 to $4.00 \mathrm{~m}$.

\section{SI-33. Rio Solimoes, Territory of Amazonas, Brazil

Charcoal from Coari site ( $4^{\circ} 6^{\prime} \mathrm{S}$ Lat, $63^{\circ} 8^{\prime} \mathrm{W}$ Long), Cut $2,80 \mathrm{~cm}$ depth. Coll. 1957 by P. Hilbert of Museu Goeldi; subm. by Clifford Evans. Sample should date the Coari Phase, Incised Rim Horizon Style. Comment: in agreement with the A.D. $763 \pm 48$ date of this culture (P-370, Univ. of Penna. VI, p. 100), based on sponge spicule temper in pottery.

\section{Arabia}

\section{Wadi Beihan series, Arabia}

Burned wooden beams from Hajar Bin Humeid ( $14^{\circ} 54^{\prime} \mathrm{N}$ Lat, $45^{\circ} 46^{\prime}$ E Long), an ancient town site in S Arabia with $15 \mathrm{~m}$ of occupational debris which has been divided into 19 periods. Coll. 1951 by D. W. Dragoo and G. W. Van Beek; subm. by Van Beek, Div. of Archaeol., U. S. Natl. Mus., Smithsonian Inst.

SI-23.

H 24. Stratum A, Room A29, $2.48 \mathrm{~m}$ depth. Comment (G.W.V.B.) : archaeologically, the complex from which this specimen comes can scarcely be earlier than the 1st century A.D. and is probably no older than the 7th century A.D. 
SI-19.

H 1280. Stratum F, Area 1, 5.77 m depth.

440 в.C.

SI-21.

H 1083. Stratum G, Area 1, 6.18 to 5.98 m depth. Comment (G.W.V.B.) : stratigraphically, this specimen should be older than or at least roughly contemporary with SI-19. It should not be younger.

\section{SI-14.}

H 2684. Stratum Q, Area 4, $11.08 \mathrm{~m}$ depth. Comment: a sample from this beam was dated at $857 \pm 160$ B.c. (W-437, G. W. Van Beek, 1956).

Date lists:

\section{References}

\begin{tabular}{|c|c|}
\hline Arizona III & Damon and Long, 1962 \\
\hline Arizona IV & Damon, Long, and Sigal \\
\hline Isotopes III & Trautman, 1963 \\
\hline Michigan V & Crane and Griffin, 1959 \\
\hline Michigan VIII & Crane and Griffin, 1963 \\
\hline Michigan IX & Crane and Griffin, 1964 \\
\hline $\begin{array}{l}\text { Univ. of Pennsylvania VI } \\
\text { USGS V }\end{array}$ & Stuckenrath, 1963 \\
\hline
\end{tabular}

Crane, H. R., and Griffin, J. B., 1960, University of Michigan radiocarbon dates V: Am. Jour. Sci. Radioc. Supp., v. 2, p. 31-48.

Crane, H. R., and Griffin, J. B., 1963, University of Michigan radiocarbon dates VIII. Radiocarbon, v. 5 , p. 228-253.

Crane, H. R., and Griffin, J. B., 1964, University of Michigan radiocarbon dates IX: Radiocarbon, v. 6 , p. $1-24$.

Damon, P. E., and Long, Austin, 1962, Arizona radiocarbon dates III: Radiocarbon, v. 4, p. $239-249$

Damon, P. E., Long, Austin, and Sigalove, J. J., 1963, Arizona radiocarbon dates IV: Radiocarbon, v. 5 , p. 283-301.

Fairhall, A. W., Shell, W. R., and Takashima, Y., 1961, Apparatus for methane synthesis for radiocarbon dating: Rev. Sci. Instruments, v. 32, no. 3, p. 323 .

Rubin, Meyer, and Alexander, Corrinne, 1960, U. S. Geological Survey radiocarbon dates V: Radiocarbon, v. 2, p. 129-185.

Stuckenrath, Robert, Jr., 1963, University of Pennsylvania radiocarbon dates VI: Radiocarbon, v. 5, p. 82-103.

Trautman, M. A., 1963, Isotopes, Inc. radiocarbon measurements III: Radiocarbon, v. 5, p. $62-79$.

Van Beek, G. W., 1956, A radiocarbon date for early South Arabia: Am. Schools of Oriental Research Bull., no. 143, p. 6-9. 